\title{
The Relationship between Social Capital and Political Participation
}

\section{Mahdi Shahin}

\author{
Assistant Professor, Lorestan Universality, Khorramabad, Iran
}

\section{Doi:10.5901/mjss.2016.v7n2s1p136}

\begin{abstract}
The aim of this study was to examine the relationship between social capital and political participation. The calibration method was used in this study. The population of the research was the staff of the Ministry of Economy and Finance and Customs of the Islamic Republic of Iran in 1394. The sample size was 200 participants. The sampling method was simple random sampling to access the participants easily. A questionnaire was used to collect the data. To measure the political participation among staff, 22 items was used. The questionnaire was divided into five levels: participation in voting, electoral activities, contact with politicians, protest activities of political groups, and membership in political groups. A questionnaire was used to measure the social capital, includes 19 items and three dimensions; social trust, social participation and social links. Face and content validity of the questionnaire were evaluated by experts. Cronbach's alpha coefficient was calculated for each variable over 7/0, and reliability was approved. To analyze the data, $t$ - student test of one sample and the stepwise multiple regressions was used at a significance level that was less than 05/0, through SPSS 19. The results showed that the average political participation and all aspects of social capital was above the average for a given (3). This indicates that the level of political participation and the social capital in the study population was in good condition. As well, the results showed that, totally, three independent variables (social belonging, social participation and social trust) formed 35.5 percent of the dependent variables.
\end{abstract}

Keywords: Social capital, Trust, Belonging, Political participation, Staff

\section{Introduction}

From the second half of 20 century, political behavior researchers have tried to examine the causes and motives of political participation (Christopher et al, 2008). Development is a process by which, human empowerment, productivity enhancement, reduction of the problems and social progress become practical. And one of the strategic elements in the development and stability of any society is "participation." In fact, according to the principles of social psychology and development literature, citizen participation is a positive event for the people and for the whole community (Monryny et al., 2009). Human beings are themselves have the potential to achieve the aspirations of the individual, collective, access to justice, solidarity, security, environmental control, etc. (Paul, 2001). On the other hand, social capital and its components such as networks, norms and trust, facilitate collective action and cooperation for multilateral benefits (Hawdon and Ryan, 2009). Increasing political trust and legitimacy lead to enhancement of citizen support of policies and acting based on the law. Collaborative networks enrich and deepen social capital and social capital strength the inner beliefs based on collective spirit and the fruit of it is to prevent the people to be particle-like. In democratic systems, social capital maintains social stability, order, and social solidarity. Social links trust, and social capital, helps the national unity through quantity and quality of political participation of citizens. Lack of trust in others decreases national integration density, because it prevents the people from participation and activeness in institutions and organizations and reduces the organized collective activism, social and political instability and crisis (Abbaszadeh and Karami, 2012).

The closer and more horizontal network relationships, the more civil engagement of people, in fact, citizens will form the inner belief through it. Social capital is "the raw material of civil society" and the phenomenon from bottom to top. The requirements for inner beliefs of citizens in democratic institutions and the dynamics of citizens within the various associations and civil society is social capital formation (Alik and Realo, 2004). Richards describes the governments with civil society to "hourglass society". The society which is determined with dense population that lives down with the strong network interaction between friends, relatives and other face-to-face and at the top of society, political life is hourglass in which the elite compete for power, wealth and prestige with each other (Arneil, 2006). Atomization and particle-like people is due to the lack of capital and poor social interaction networks that result in the vulnerability of the state and society against the power of the collective action of mass destruction. Social capital is fundamental in relationship between the people with the actions of the organization and connects them to the community. Social associations make connection and interaction with each other, and cause the emergence and survival of state power stability and political 
discourse (Walters, 2002).

In a country the government and society complement each other and help themselves in the rush to meet the challenges ahead by having good governance and high levels of social capital. Appropriate levels of social capital lead to the knowledge development in society and make individuals responsible. More consolidation reduces crime and in fact, reduces the official control of citizens, and indeed, internalized norms that have been formed through socialization of people, on one hand reduce governmental expenditure and the other hand strength the relationship between people and government, also increase their flexibility (Macke, 2007). If citizens have more dependence to groups and associations, in a close and horizontal form, the social capital is greater and civic involvement of people enhances and then, government accountability and flexibility will increase (Chou and Lim, 2010). As Putnam noted, trust and cooperation is cumulative and self-reinforcing, and a circle of trust lead to civic engagement and higher levels of cooperation and that this leads to efficiency and accountability of the government and the rule will be good. Societies that are quite separate, trust, partnership, positive network cooperation and bilateral interaction between members are less than other societies. This in turn will have a negative effect on the quality of members' life. In fact, the divided communities invest more on the negative side of social capital, and it would reduce the flexibility of individuals and groups and have a significant role in their reluctance to national identity (Putnam, 2000).

Cooley believes that an individual action in the daily life is under the influence of those groups that belongs to them and the group dependency determines the way that people react to the political issues. And in fact, the individual behavior is formed in response to the pressures and social expectations on the part of friends and family. According to this view, people think in a way that lives in it (Alvani and Seyyed naghavy, 2002). According to symbolic interaction approach, central features of social action in "own" people and their understanding of the behavior of others is formed. In the framework of this approach, we can consider the opinions of Mead and Cooley. In Meads' opinion the "own" in each individual obtains through the groups' opinions. And without other ideas we have no identification from ourselves (Macke, 2007). In a family, parents transfer the political values and their attitudes to the children through the discussion at home and in this way they assert their willingness or unwillingness toward the political issues. School, friends and classmates and mass communication by providing information and interpretation of political world affect the thinking and political behavior of people and people think socially in a way that they politically lives Nezhad et al.( 2007). In this regard, the aim of this study is, firstly: to evaluate the political participation and social capital among the employees of the Ministry of Economy and Finance and Customs of the Islamic Republic of Iran, Secondly: to assess the relative contribution of social capital and its components on the changes in the willingness on political participation in the society.

\section{The Empirical Studies}

Fathi (2006), conducted a study entitled "Exploring the Effect of Social Factors on Political Participation of Youth in Islamshahr" The questionnaire distributed among 251 young people aging 18 to 34 years old in Islamshahr. The results of the study showed that the major variance of the political participation of young people at the first step was determined through the micro-level of intellectual wisdom i.e. the political socialization variables (Variable of friends and political family) and in the second and third stages respectively, they were determined through macro objective and subjective variables. While the micro-level variables did not have any significant relationship with participation. In fact, the youth in solitude and isolation cannot develop their characters. In addition to family influence in the development of political and social character, other institutions such as friends and peers can affect the development and growth of youth through centers such as schools, universities etc. The findings suggested that political activists have family and friends and they participate in elections and rallies and engage in political debate.

Movahed et al. (2008), did a study entitled "The relationship between social capital and political participation of women". This study was conducted on 398 of eighteen years old and older women living in Shiraz; the participants were divided into two groups of employed and unemployed. By dividing the social capital into four dimensions, and considering the political participation aspects i.e. the attitude toward participation and the way of participation can be seen that there is a significant correlation between the dimensions of social capital and political participation. According to the results, there is a need to provide an appropriate environment for women to expand existing networks of social relations and strength the links based on the intimacy and interest, especially in the family.

Ja'farinia (2012), carried out a study entitled "The Effect of socio - economic factors on the political participation of citizens in Khormoj ". The population of the study consisted of all persons 18 and older in Khormoj. The most important results were as follows: the amount of desire for political participation among men was more than women, with an increase in education, political participation tends to increase well, and the higher social class had more desire than lower social classes for political participation. The age, location and marital status had no relationship with the desire for 
political participation. Among the variables, education and organizational relations variables with beta 0.47 and 0.28 had a significant impact on the willingness to political participation.

Using linear combination variance of independent variables, $52.5 \%$ of the variance was determined the willingness to political participation. Ebrahimi et al. (2012), conducted a study entitled "The relationship between social networks and political participation among Isfahan university students". The main question of this article was that the electoral behavior of students as one of the main indicators of political development were on the basis of what criteria and what is the role of social networks in determining the direction of this criterion? The purpose of this paper was to examine the relationship between social networks and electoral behavior among students in the university. By dividing the social networks to the three-dimensional network of vertical, horizontal and qualities of social networks, as well as considering four aspects of political participation i.e., formal, informal and objective dimensions observed that horizontal networks have the most impact and the social networks have the least impact on students' political participation.

Emam Jomezadeh and et al. (2012), did a study entitled "The relationship between social capital and political participation among Isfahan university students". The participants of the study were 188 male and female students of Isfahan University. With the division of social capital into 3 variables (social trust, social norms and social networks), and consideration of two aspects of political participation i.e. the psychological factors, attitude and participation practices (formal or informal), observed the significant solidarity of the dimensions of social capital and the amount of the accountability political participation.

Emam Jomehzadeh and et al. (2014), have done a study entitled "The Role of the structural aspects and social capital communication in explaining political participation (a case study of Isfahan university students)". By dividing social capital into two dimensions of structural and communicational and political participation with three levels of political indifference, formal political participation and active political participation, the results showed that although two dimensions of social capital has a meaningful relationship with political participation dimensions, but communicational social capital has more impact on political behaviors of students.

Movahed (2003) investigated the relationship between social capital and political participation of women. This study included 398 female aging 18 and above in Shiraz through calibration method. The result showed that there is a significant correlation between social capital and the amount of political participation of females.

Kointeru et.al (2011), in as study entitled" politics in peers:

The relationship between the network variety and political participation" investigated the effect of tribal, cultural, and political kinds in social networks on political participation among 4235 Belgic youth. They found that by having different social and political networks, the political participation increase and this issue causes the various political contacts with others.

\section{The Definition of Concepts}

Political Participation: The definition that is more common todays is a new phenomenon and particular in modern government. Different definitions of political participation reflect the lack of consensus on the definition, indicators, and parameters of this phenomenon. However some scholars limit this concept in a power and influence circle, others represent it beyond the formal institutions of government. Totally, it can be said that political participation is a set of activities and the power of citizens on government or supporting the political system (Fakouhi, 2004).

Political participation: voluntary activity of community members in choosing the leaders and participating in public policy directly and indirectly (Mosafa, 1996; quoted Sedighi et al, 2011). According to Milberas and Goel, political participation of people depends on four factors. Political motivation, social status, personal characteristics and political environment. The skills, resources, and trust should be added to these factors. For example, the more a person encounter the political discussions and have more political motivation toward an organization that he works, or access to political information, the more political participation potential he has. But, participation based on individual characteristics is different. More social character, more dominant and more extraneous person are more likely to be politically active. Social status which is measured by level of education, location, class and ethnicity, have more impact on participation. Environmental or political context is also important (Rush, 1998).

Social capital: Social capital refers to the resources that people through membership in a social group has access to it, this group can be a great nation or a small family. Resources can be something tangible like money, housing, jobs, social protection and non-tangible features such as useful information, advice and peace of mind. A person with lots of "social capital" is one that has broader relationships, intimacy, significant and deep trust. According to what was said, it can be said that social capital fertilize through accumulation and interaction of physical, human and cultural possessions, and move the country toward its future ( Tajbakhsh et al., 2006). Kolman, Putnam, Bordio, and Fokoyama's approaches 
toward social capital are similar to each other. And all of them can be placed on network approach that focuses on triple axes:

1. Social Trust: social trust is a fundamental concept in social capital that is considered as normative, subjective and cognitive dimension. This trust is the result of social interactions in groups, forums and social activities, and if the confidence of the individual level transfers to

The social level, it becomes a valuable asset.

2. Social Participation: One of the important components of social capital that is a product of the social relations network is the level of citizen participation in the social system. In fact, social participation is a process that has been done with awareness, voluntary, and collective. And it has a certain goal in order to share different valuable resources. The objective example of such participation is in religious and social celebrations and ceremonies that person shows a cooperative action through it.

3. Dependency or belonging (social links): It includes social links based on similarities and intimacy. Here the emphasis is more on limited personal resources. Family ties, neighbors and close friends, are included in social capital. These links include both normative and structural dimensions (Volkak, 2001, quoted by Field, 2007).

\section{Research Hypothesis}

1. The desire for political participation among employees is higher than the average.

2. The components of social capital among employees are higher than the average.

3. The proportion of components of "social capital" variable in explaining the changes in political participation among employees is positive and significant.

\section{Research Methodology}

This study categorized as an applied research. Also in terms of implementation and objectives of the survey the calibration method was used to obtain the data. The participants of the study were the staff of Ministry of Economy and Finance and Customs of the Islamic Republic of Iran in 1394. The sample size was 200. The sampling method was simple random sampling. To collect the data, questionnaire was used. To measure the political participation among the staff, 22 items was used. This questionnaire was divided into five levels of participation in voting, electoral activities, contact with politicians, membership of political groups, and doing protest activities. The items were set in Likert items from strongly agree (5), agree (4), no idea (3), disagree (2) and strongly disagree (1). In order to measure the social capital a researcher-made questionnaire which includes 19 items and was divided into three dimensions: a) the social confidence (7) items. The items in 5 Likert spectrum degree were set from very high (5), high (4), average (3), low (2) and very low (1). B) The social participation consisted of 5 items. The items in 5 Likert spectrum degree were set from very high (5), high (4), average (3), low (2) and very low (1). C) The social link consisted of 5 items. The items in 5 Likert spectrum degree were set from strongly agree (5), agree (4), no idea (3), disagree (2) and strongly disagree (1). Then the questionnaires were given to some experts and they revised them. As a result, the content and face validity of the questionnaires were assured. Cronbach's alpha coefficient was calculated for each variable over 7/0, resulting in reliability. To identify the research hypotheses, test inferential (t- student and one example of the stepwise multiple regression) at a significance level of less than 05/0, was used. In this regard, the SPSS version 19 software was used.

\section{Results}

As shown in Table 1, the one-sample t-test evaluated the significant difference between actual and assumed political participation variable of the first hypothesis, and it is smaller than $05 / 0$, thus the null hypothesis that the average value of it is equal to 3, was not approved. On the other hand, the two numbers shown in related column 95\% (top and bottom) suggested that these values are in the same direction for these variables. Low and high of this gap was positive, and it indicated that the average respondents' views about these components was greater than the number 3 and the results of the analysis of the data showed that the average statistic t-value, the critical value was bigger than 1.96 and was located in the critical area, in other words the difference between the average number of 3 was significant, so the political participation was higher than assumed average of (3) and first hypothesis was confirmed. And this showed that the political participation in the study's sample was in good condition.

According to Table 1, it can also be said that the one-sample t-test evaluated the statistically significant difference 
between the two actual and assumed average of social capital variable including, social trust, social participation and social links to measure the second hypothesis, and it was smaller than 05/0, thus the null hypothesis was not confirmed that the average variable is equal to 3 . The t statistic was higher than 1.96 and was located in critical area, and in other words, the difference of average from (3) was meaningful. Thus, the average of all aspects was higher than the assumed average of 3 and the second hypothesis was confirmed. And this indicated that the amount of social capital among community staff was desirable.

Table 1: T-test in order to investigate the difference between two actual and assumed variables of this study

Test value $=3$

\begin{tabular}{|c|c|cccccc|}
\hline \multicolumn{9}{|c}{$\% 95$} & AD & ML & df & amount t & & \\
Upper level & Lower level & am & & & & \\
14.6653 & 13.1034 & 13.88435 & .000 & 199 & 35.138 & 4.79085 & 16.8844 \\
\hline 7.4812 & 6.8265 & 7.15385 & .000 & 199 & 43.084 & 2.39472 & 10.1538 \\
11.0779 & 10.4221 & 10.75000 & .000 & 199 & 64.635 & 2.39867 & 13.7500 \\
\hline 8.7763 & 7.7045 & 8.24038 & .000 & 199 & 99.146 & 5.23572 & 10.2404 \\
\hline
\end{tabular}

variable

Political participation

Social trust

Social participation

Belonging (social link)

The third hypothesis: the relative contribution of the component of "social capital" variable in explaining changes in political participation among employees was positive and significant.

- Step 1: According to Table 2, the first predictor variable of political participation that entered into the regression equation was social belonging variable that determined $29.2 \%$ of variance of political participation. The standard regression coefficient of this variable is ( $\beta$ : 0.547$)$ that shows the relative contribution of independent variable in prediction of dependent variable changing. In other words for every one unit enhancement in social belonging variable of staff, the political participation increases about 5 percent.

- Step 2: In the second stage, the social participation entered into the regression equation and about $33.3 \%$ of dependent variable variance was determined. By entering this variable, about $4 \%$ was added to predictive power of the model. The standard regression coefficient of this variable is ( $\beta$ : 0.224$)$ that shows the relative contribution of independent variable in prediction of dependent variable changing. In other words for every one unit enhancement in social participation variable of staff, the political participation of them increases about 2 percent.

- Step 3: In the third stage, the social trust variable entered into the regression equation and about $35.7 \%$ of dependent variable variance was determined. By entering this variable, about $2.4 \%$ was added to predictive power of the model. The standard regression coefficient of this variable is $(\beta: 0.197)$ that shows the relative contribution of independent variable in prediction of dependent variable changing. In other words for every one unit enhancement in social trust variable of staff, the political participation of them increases about 2 percent.

Taken together, these 3 variables have determined $35.7 \%$ of the changing of dependent variable.

Table 2: The result of stepwise regression analysis of test about the effective factors on political participation

\begin{tabular}{|c|c|c|c|c|c|c|l|c|}
\hline Sig.F & $\mathbf{F}$ & Sig.T & $\mathbf{T}$ & $\boldsymbol{\beta}$ & $\mathbf{R}^{2 . a d j}$ & $\mathbf{R}$ & Predictor variables & $\underline{\mathbf{E}}$ \\
\hline $0 / 000$ & $40 / 618$ & $0 / 000$ & $6 / 373$ & $0 / 547$ & $0 / 292$ & $0 / 547$ & Social belonging & 1 \\
\hline $0 / 000$ & $24 / 971$ & $0 / 01$ & $2 / 614$ & $0 / 224$ & $0 / 333$ & $0 / 589$ & $\begin{array}{l}\text { Social belonging } \\
\text { Social participation }\end{array}$ & 2 \\
\hline $0 / 000$ & $18 / 755$ & $0 / 37$ & $2 / 116$ & $0 / 197$ & $0 / 357$ & $0 / 614$ & $\begin{array}{l}\text { Social belonging } \\
\text { Social participation } \\
\text { Social trust }\end{array}$ & 3 \\
\hline
\end{tabular}

\section{Conclusion}

Here are the summary of the findings:

The average of political participation and also the total average of social capital variable were higher than (3). This finding suggests that the political participation and social capital among the staff was desirable. Also the first predictor variable of political participation that entered into the regression was social belonging that determined $29.2 \%$ of political participation variance. The obtained result was in line with the results of Movahed et al. (2008) and Ebrahimi et al. (2012) 
and confirmed them. In the second phase, the social participation entered into the regression and about $33.3 \%$ of variance of dependent variable was determined. This result was in line with the results of Jomezade et al. (2014) and Kointru et al. (2011) and confirmed them. At last, in the third phase, the social trust entered into the regression and about $35.7 \%$ of the variance of dependent variable was determined. This result was in line with the results of Emam Jomezade et al. (2012) and confirmed them.

To clarify the results of the study, it can be said that social capital in fact, reflects the fundamental relationship between the individuals and organizing their actions. In other words, the presence of the capital in an efficient society causes that citizens perceived social responsibility for themselves and they will provide their demands in order to progress in the face of sympathetic critic. Therefore, achieving sustainable national security requires that the government do not neglect the social issues and this capability ensures the appropriate and correct application of social capital, and as a result, the people participation will increase. On the other hand, the concept of social trust has an inner relation with social relations in the society. The result of the formation of the social trust is to perform different tasks, and then participate in political affairs. Social trust as one of the participation dimension strength the social trust, growth, and production. Social trust is one of the most important and influential factors in planning and enriching the social culture, political and social institutions and organizations that promotes and strengths trade and professional partnership between individuals and institutions, thereby it helps participation in various fields, including politics.

The results of the study showed that there is a relationship between social capital and its components with a tendency to political participation in staff. So suggestions are offered as follows:

- Developing the organizations and voluntary and non-governmental associations should be a priority for policy makers and community practitioners to thereby motivate individuals and communities to take steps towards a more dynamic society. It is necessary to develop social trust, especially institutional in a society as one of the appropriate solutions that needs to be tried. Therefore, on the one hand, we can raise the level of institutional trust in the society, the motivation to participate in voluntary organizations and associations, also increase the political events and on the other hand, develop and strength the relations that play a crucial role in political capital.

Since the media plays an important role in the socialization and internal resources that constitute social capital, they should strength social solidarity and promote a sense of unity in society and provide the humans for their social participation through the socialization and internalization of rituals, customs, rituals, habits and social traditions.

- Furthermore, the media should increase the adaptability in society and power structure through socialization and behavioral pattern, so it can have crucial role in political participation.

As well, the media should try to identify individual needs and reflect them to the government, create the necessary environment for political civilization, the expansion of social relationships, shaping the public domain and the creation of social trust as prerequisites for political participation.

- The media can create the required infrastructure for the development of political civilization, political legitimacy and social relations in this context. Media should try to teach people about the principles of citizenship, enlighten and inform them about their rights, strength national integration and develop social relationships.

\section{References}

Abbaszadeh, Hadi; Karami, Kamran(2011). Social Capital and Stable Security. Rahbordi Studies, $4^{\text {th }}$ year, First No. successive 51, p. $31-58$

Alvani, Seyyed Mahdi; Seyyed Naghavi, Mirali (2002).Social Capital, Concepts, Approaches. Management studies, No.33-34 .p.4-26

Alik, J.\&Realo, A. (2004). "Individualism-Collectivism and Social Capital", Journal of Cross-Cultural Psychology, Vol. 35, No. 1.

Arneil, B. (2006). Diverse Communities The Problem with Social Capital, Cambridge: Cambridge University press.

Christopher T. Dawes, Peter J. Loewen, James H. Fowler (2008). "Social Preferences and Political Participation", Political Behavior, Vol. 12. No 3, pp 289-314.

Chou, A \& Lim, B. (2010) "A framework for measuring happiness in online social network". I11inois state university.

Ebrahimi, Shahrooz; Najafi, Davvod; Mahmood Oghali, Reza; Sadeghi, Naghali, Zahra (2012). The Relationship between Social Networks and Political Participation among Isfahan University's Students. Rahbord Quartely, $2^{\text {nd }}$ year, No.66 p. $263-284$

Emamjome zadeh, Seyyed Jvad; Rahbar Ghzi, Mahmoodreza; Eisa Nezhad, Omid; Mrandi, Zohreh(2012). The Relationship between Social Capital and Social Participation among Isfahan University's Students. Political studies bulletin, $7^{\text {th }}$ year, No. 4 p. 7-34

Emamjozadeh, Seyyed Jvad; Mehrabi Kooshki, Razieh; Rahbar Ghazi, Mahmoodreza (2012). The Effect of Structural Dimension Role and Social Capital Communication I Determining Social Particiaption (Case study: Isfahan University Students). Rahbord Quarterly, 23rd , No. 70, p. 153-177

Fathi, Mohammad Hossein (2006). The Effect of Social Factors on Political Participation of Islamshahr Youth. M.A. in sociology, Tehran University, Supervisor: Saeed Moeedfar.

Fakouhi, Naser (2004). " Humanism theory on villager think about political participation ". Sociology magazine, NO.26. pp 25-67(in 
persion).

Field, Jan(2007). Social Capital. Translation: Gholamreza Ghaffari and Hossein Ramezani, Tehran: Takvir Press.

Hawdon, J \& Ryan, J. ( 2009). "Social Capital, Social Control, and Changes in Victimization Rates", Crime \& Delinquency, Vol. 55, No. 4. Jafari nia, Gholamreza (2012). The Effect of Social-Economical Factors on Political Participation of Khormoj Citizens.7th period, No. 2.

Movahed, Majid (2003). " women political participation and effective social factors on it ( item study of Banddar Abbas )" women study magazine. First year, NO.3, PP 3-28(in persion).

Mannarini. Terri, Fedi. Angela, Trippetti. Stefania, (2009). "Public Involvement: How to Encourage Citizen Participation"Journal of Community \& Applied Social Psychology, 20: 262-274 (2010). Published online 8 December 2009 in Wiley InterScience.

Macke, J. (2007). Collective Competence and Social Capital Analysis in Collaborative Networks. Strategic Management Journal, V. 24, N.10, p. 7

Movahed, Majid; Enayat, Halime; Pournemat, Arash(2008). The Relationship between Social Capital and Political Participation of Female. Social and Humanities Bulletin" Special Issue of Social Studies" p. 161-191.

Macke, J. (2007). Collective Competence and Social Capital Analysis in Collaborative Networks. Strategic Management Journal, V. 24, N.10, p. 7.

Nezhad. M and Hosssein Zade. A and Moazami Godarzi. (2007). Social capital: conceptual and measurements. Quarterly Journal of Hnman Development‘Vol1 ، No 4.

Putnam, R (2000). Bowling Alone: The Collapse and Revival of American Community. New York: Simon and Schuster.

Pol, E.(2001). La participacionAmbiental. Problemas y Experiencias Class booklet of.

Quintelier, Ellen, DiettlindStolle and Allison Harell (2011). "Political in Peer Groups: Exploring the Causal Relationship between Networks Diversity and Political Participation, Political Research Quarterly.

Rash Michael (2002). Society and Politics. Translation of Manoochehr Saboori. Tehran, Samt Press.

Sedighi, Behrang; Malekian, Lina; Ojaghi Azbari, Mehdi (2011). The Effect of Trust on Political Participation (M.A Students of Rudehen private University 88-89). Social Research Quartely, 4th year, No. 11, p. 171-188.

Tajbakhsh, Kian; Saghafi Morad; Koohestani Nezhad, Masoud (2006). Social Capital and Social Politics (The investigation of Social Capital Situation IN Iran). Social wealth, p.155-197

Walters, W. (2002). "Social Capital and Political Sociology: Re-imaging Politics?", Sociology, Vol.36, No.377. 